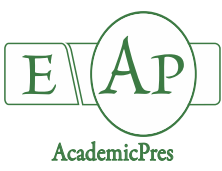

Kovács Zs. et al. (2021)

Notulae Botanicae Horti Agrobotanici Cluj-Napoca

Volume 49, Issue 2, Article number 12334

DOI: $10.15835 /$ nbha49212334

Review Article

\title{
Ex situ conservation in botanical gardens - challenges and scientific potential preserving plant biodiversity
}

\section{Zsófia KOVÁCS ${ }^{1 *}$, Anna Mária CSERGÖ ${ }^{1}$, Péter CSONTOS², Mária $\mathrm{HÖHN}^{1}$}

\author{
${ }^{1}$ Hungarian University of Agriculture and Life Sciences, Institute of Agronomy, Department of Botany, Ménesi street 44, Budapest \\ 1118, Hungary; zsofia.kovacs42@gmail.com (*corresponding author); \\ Csergo.Anna.Maria@uni-mate.hu; Hohn.Maria@uni-mate.hu \\ ${ }^{2}$ Institute for Soil Sciences, Centre for Agricultural Research, Herman Ottó street 15, Budapest 1022, Hungary; cspeter@mail.iif.hu
}

\begin{abstract}
In the Anthropocene, the world's plant diversity is threatened with extinction and the erosion of the genetic diversity of natural populations. According to the State of the World's Plants and Fungi 2020 of the Royal Botanic Gardens, Kew, two out of five of the $~ 350,000$ known vascular plant species are at risk of extinction. Despite the considerable toolkit of biodiversity conservation practices, usually it is hard to choose the best option to stop biodiversity loss. EX situ conservation has seen massive development due to radical losses of natural ecosystems, and its incrementing necessity has been underscored by Target 8 of the 2011-2020 Global Strategy for Plant Conservation. As we crossed the finish line of this strategy in 2020, a review of the accumulated knowledge on the ex situ living collections has become particularly important. Despite the increasing attention received by ex situ conservation, studies on the sustainability, quality, and usability of the plant material prior to establishing the garden collections are few, leaving major gaps unfilled in terms of best ex situ conservation practices. Here we present an overview of the results and experiences in ex situ conservation focusing on living plant collections, with the aim of guiding conservation practitioners towards the most efficient working methods. We evaluate the future needs and perspectives of this conservation technique, based on case studies on both woody and herb species. Possible conservation applications and priorities suggested for future works are summarized.
\end{abstract}

Keywords: biodiversity conservation; ex situ; functional traits; genetic diversity; living collections; review

\section{Introduction}

Ex situ (off-site) methods are the "Noah's Ark" approaches that complement in situ plant conservation in alleviating the negative consequences of habitat loss (Falk, 1987; Given, 1987; Brown and Briggs, 1991; Volis and Blecher, 2010). Ex situ conservation mitigates the extinction risk of species and populations by displacing the genetic resource to a new place such as seed banks, field gene banks, or to living collections located mainly in botanical gardens. As a result, ex situ conservation can fulfil a wide range of purposes and roles: (1) preserve 
a representative sample from a species' genetic material, i.e., represent the germplasm backup against extinction (2) have an important educational and demonstration role, (3) offer a viable alternative to commercial harvesting from natural populations, (4) propagated individuals can be used to re-establish or enrich wild source populations, (5) represent long-term gene reserves and preserve functional traits for future use (Brown and Briggs, 1991; Maunder et al., 2001; Guerrant et al., 2004; Volis and Blecher, 2010). Further, ex situ collections provide study opportunities on a species' genetic material without harming the original wild source (Li and Pritchard, 2009).

EX situ methods include a wide variety of techniques depending on the source material, intensity of maintenance and financial possibilities, e.g. cryopreservation (seeds, pollen or tissue stored in liquid nitrogen), tissue culture (storage or propagation), field gene banks, living collection, DNA reserves and seed banking (Maunder et al., 2004; Hawkes et al., 2012).

Combined methods better secure the long-term conservation of a species against unexpected events. $E_{X}$ situ management of germplasm starts with the collection of propagules (seeds or planting material), which after a short-term conservation period undergo a regeneration and/or multiplication phase (depending on the initial material). The subsequent conditioning/harvesting and cultivation phase provides opportunities to evaluate the germplasm' viability, vigour, vitality and health, as well as to evaluate the success of the ex situ conservation method used. Propagule collection and conditioning are followed by the final step, the repatriation (Pineda et al., 2007).

Ex situ conservation has undoubtedly limitations, including the erosion of the original genetic material due to genetic drift, inbreeding, outbreeding, accumulation of deleterious alleles, hybridization and introgression (Volis, 2017; Ensslin and Godefroid, 2019; Nonić and Šijačić-Nikolić, 2019). Phenotypic changes such as loss of seed dormancy, increased germination rate, phenological and growth shifts, as well as changes in reproduction and competitive ability are typical signs of the altered original, wild material. Moreover, novel garden conditions can induce evolutionary shifts leading to e.g., loss of adaptation to drought stress, loss of interspecific competition ability or profound changes to phenotypic traits, and thus to unconscious selection (as consequences of horticultural assistance) and domestication syndrome (trait changes associated with genetic changes due to domestication) (Hammer, 1984).

Seed banking, cryopreservation and in vitro conservation are alternative, mostly cost-effective ex situ methods (Maunder et al., 2004). Plant species can be preserved in seed-banks for many years without serious deterioration, therefore many of the problems can be avoided like the genetic erosion or selective change in genetic constitution of species (Thompson, 1974). The tendency of ex situ conservation via seed banking is increasing, there are at least 350 seed banking botanical gardens in 74 countries preserving almost 57,000 taxa (O'Donnell and Sharrock, 2017). Millenium Seed Bank Partnership (MSBP) is the largest wild plant conservation program and has developed seed conservation standards which characterize recent best practices for long term conservation of orthodox seeds (MSBP, 2015; O'Donnell and Sharrock, 2017; Liu et al., 2020). Living collections of the global botanical garden network preserve at least 105,634 plant species, which represent 59\% of all plant genera (Mounce et al., 2017). Because seed banking, cryopreservation and in vitro conservation need totally different preservation premises and conditions, these methods are not discussed within the frame of this paper.

Studies preceding the establishment of ex situ collections are few, and those following the establishment of ex situ collections are heavily imbalanced towards the investigations of the variability of cultivated populations ("cultivated varieties") used for ecological restoration. Phenotypic changes incurred by the ex situ populations relative to the wild source populations are even less frequently reported (Ensslin and Godefroid, 2019). In efforts to improve ex situ preservation practices, several general recommendations have emerged. For example, preserving larger population sizes is generally preferable to prevent genetic erosion and decrease the consequences of genetic drift and inbreeding (Volis, 2017; Ensslin and Godefroid, 2019). It is not easy to design a clear and exact roadmap for ideal population sizes due to species' different mating types and reproductive strategies in plants (Basey et al., 2015; Ensslin et al., 2015), therefore 100 to 1000 individuals are thought to be 
sufficient in maintaining adaptive genetic diversity (Frankham et al., 2014; Basey et al., 2015). Further recommendations intended to limit genetic drift and inbreeding include periodically repeated introduction of new genetic material, controlled pollination, and pollinator placement in the vicinity of the collections. To avoid hybridization and introgression, closely related accessions should be planted at a minimum of a few hundred meters apart (Basey et al., 2015). To prevent changes and shifts in traits it is highly recommended to collect even numbers of female and male individuals and to sample from all mother plants that will produce the next generation. Unconscious selection should be prevented by planting both the early and late germinating seedlings in the ex situ population (Volis, 2017; Ensslin and Godefroid, 2019). To prevent evolutionary changes and adaptation to garden condition the number of ex situ generations should be limited to 2-5 generations and adjusted to the species' lifespan and life form (short-lived species with fast changes over a few generations are more affected) (Schoen and Brown, 2001; Havens et al., 2004; Prasse et al., 2010). Simulating the original habitat or planting the plants to a more natural site which is maintained by the botanical garden (quasi in situ) can as well prevent genetic changes and adaptation processes (Volis and Blecher, 2010).

It is thus clear that establishing a representative germplasm requires careful planning because genetically non-representative samples or their poor documentation can jeopardize conservation attempts (Maunder et al., 2001; Maunder et al., 2004). Without studying the wild population structure and species history, optimal sampling designs are difficult to envisage (Hoban and Schlarbaum, 2014; Hoban and Strand, 2015; Hoban, 2019). Following the establishment of novel populations, it is critical to evaluate the effectiveness of the different ex situ, and alternative quasi in situ techniques used (Ensslin and Godefroid, 2019).

As many taxa have already been preserved in ex situ collections, and the number of studies related to wild species ex situ conservation are also rapidly growing, reviewing current knowledge and assembling experiences of the ex situ collections has become particularly important. Target no. 8 of the 2011-2020 Global Strategy for Plant Conservation recommends that "At least 75 percent of threatened plant species should be preserved in ex situ collections, preferably in the country of origin, and at least 20 percent available for recovery and restoration programmes" (GSPC). Expiring target goals bring up questions about the sustainability, quality, and usability of the collections for future successful conservation activities. In this review we focus on the problems and drawbacks of the ex situ methods, as these have a great impact on the living collections, as well as on the field gene banks. Hereafter we use the term ex situ related to these conservation methods. Furthermore, we synthesize the state-of-the-art of ex situ conservation and we present a summary of the key aspects (e.g. environmental, genetic, demographic) important for an efficient, long-term ex situ conservation, highlighting the study gaps where necessary. We focus on two major study groups recommended for simultaneous and realistic evaluations of ex situ conservation success (Wei and Jiang, 2020): genetic studies and morphological trait measurements and examinations. We conducted an extensive search through the available literature using ScienceDirect Core Collection, Google Scholar and Web of Science. We used the following keywords: 'ex situ', 'wild plant' and 'conservation' and selected the articles related to living plant collections at a global scale.

\section{Genetic studies in ex situ populations}

\section{The challenge of preserving genetic diversity}

One of the long-term goals of ex situ conservation is to preserve the maximum level of genetic diversity of a species, and its source populations. Ex situ living collections like seed banks or tissue culture, because of the limited space, can be interpreted as small, isolated populations of a species (Maunder et al., 2001), which are inherently exposed to genetic risks such as genetic drift, inbreeding depression or founder effect (Lande, 1994; Husband and Campbell, 2004). Genetic drift is the main acting force against the Hardy-Weinberg equilibrium (i.e., the optimal state of a population, when allele and genotype frequencies are equilibrated and remain stable over the next generations), causing random change in allele frequencies from generation to generation due to 
stochastic events (Allendorf et al., 2013). As a consequence, genetic drift may reduce the fitness of individuals and limit the evolutionary potential of ex situ populations (Ensslin and Godefroid, 2019). Such forces acting on the genetic composition of populations usually do not affect hard populations which are in HardyWeinberg equilibrium (Allendorf et al., 2013) but hit non-equilibrated populations such as the ones established ex situ. Inbreeding depression occurs in small populations when related individuals' mate with each other, causing increased homozygosity and loss of alleles. Mating strategy and pollination mode greatly influence the possible inbreeding rate. However, we know little about the natural inbreeding rates of most wild plants, making a priori field studies necessary to evaluate possible consequences of inbreeding under ex situ conditions (Allendorf et al., 2013; Ensslin and Godefroid, 2019). The founder effect is another great challenge to populations established ex situ with a small number of individuals, because rare and unique alleles can be left out from these founder populations, resulting in underrepresented genetic variability. Moreover, a small ex situ population can preserve deleterious alleles at higher frequencies compared to natural populations, which can lead to population extinction on the long run (Allendorf et al., 2013). In the last decades, new molecular markers such as AFLP (amplified fragment length polymorphism), ISSR (inter simple sequence repeat), SSR (simple sequence repeat) and SNP (single-nucleotide polymorphism) can highlight population genetic traits at increasingly finer resolution, continuously improving the chances of better population sampling for $e x$ situ conservation.

The importance of preserving unique alleles and sampling from the whole distribution area of the target species

It is increasingly recognized that the full breadth of genetic variation of a species is the additive genetic makeup of all populations across the distribution range. Narrow endemic, rare and endangered species' populations in different ecological environments across the range may undergo local adaptation or experience genetic drift, due to which they may hold unique alleles or allele combinations that need to be captured under ex situ (Lesica and Allendorf, 1995; Vitt and Havens, 2004; Hampe and Petit, 2005; Allendorf et al., 2013). Unique alleles can carry information on important functional traits that could be key for a species' survival under special scenarios such as rapid climate change (Reyes-Valdés et al., 2018). If some populations carrying important genes are omitted from ex situ collection, the long-term evolutionary potential of the species will be altered, the viability of its ex situ or reintroduced populations can decrease and the extinction risk of the species increases under environmental change (Etisham-Ul-Haq et al., 2001; Silva et al., 2020). Therefore, evaluating population variability across the species' entire area of distribution becomes critical for guiding the sampling strategies. For example, if there is a higher variability between populations than within populations, a proper strategy for any taxon would be to collect only a few individuals per population but from many populations throughout the whole range to preserve the integrity of the original species genome (Cochrane, 2004). However, capturing and preserving unique alleles is not an easy task, and ex situ collections report mixed success. For example, Vatica guangxiensis S.L. Mo is an endangered plant species of China with a low level of genetic variation in the natural populations. While the ex situ collection had intermediate genetic variation, exclusive alleles from the natural populations were not retrieved in the garden collection, and more extensive sampling was needed before future restoration and repatriation (Li et al., 2002). Conversely, other ex situ conservation attempts managed to preserve very high rates of private alleles. In Leucothrinax morrisii (H.Wendl.) C. Lewis \& Zona, an endangered taxon of Florida, USA, the mean diversity (He) was similar between the ex situ collection and wild populations, and the allelic capture was greater than $94 \%$ (Namoff et al., 2010).

EX situ collections may even preserve unique alleles that have already been lost from the natural sites. In a study of Taxus yunnanensis W. C. Cheng \& L. K. Fu based on microsatellite markers, Miao et al. (2015) detected 23 unique alleles in cultivated populations and just 14 unique alleles in natural populations. Such alleles may hold important attributes for a species' future survival, and the importance of their preservation and reintroduction in the wild is outstanding. Similarly, in a study on Zelkova carpinifolia (Pall.) K. Koch five new 
haplotypes were identified in ex situ collections that were not matched in the wild populations (Christe et al., 2014).

Despite the widespread knowledge of the theoretical underpinnings, the geographic representation of populations reported in former ex situ collections is often poor, but there are outstanding exceptions. A case study on Berberidopsis corallina Hook.f., a threatened and endemic vine of Chile showed a high degree of genetic differentiation between Northern and Southern wild populations that likely represented two distinct refugia. The genetic diversity of ex situ collections was similar to the rate recorded in small natural populations, but it only encompassed the genetic material of the Northern populations, and the species ran the risk of losing important alleles. To fix this shortcoming the authors called for the establishment of a new ex situ collection that would include the Southern region (Etisham-Ul-Haq et al., 2001). In a comparative molecular analysis of Zelkova abelicea (Lam.) Boiss and Zelkova carpinifolia (Pall.) K. Koch using cpDNA markers, the ex situ collections of the two species represented unequally the variability of the corresponding natural populations (Christe et al., 2014). While the stands of both species had lower variability than in the wild, $Z$. abelicea preserved only two out of 33 haplotypes in the wild populations, which most probably originated from a single region. Zelkova carpinifolia (Pall.) K. Koch on the other hand successfully preserved 12 out of the 15 wild haplotypes, which belonged to two genetically distant phylogeographic regions (Eastern and Western cluster).

Sampling from across species' whole area of distribution often safeguards unique and important alleles if the geographic distribution subsequently shrinks or the in situ populations become extinct. Wilson et al. (2017) evaluated and compared the genetic diversity of the endangered Zizania texana Hitchc. in situ populations from the San Marcos River and ex situ population in the San Marcos Aquatic Resources Center, using six microsatellite markers. Overall, the ex situ populations exhibited lower allelic diversity but some natural population "segments" have decreased in size, therefore the conservation value of the ex situ stand that holded unique and important individuals has increased. In concert with studies that revealed poor geographic representation in ex situ stands, Wilson et al. (2017) underscored the necessity of capturing all unique alleles to secure the genetic diversity of the wild populations, which can be achieved by a more extensive sampling and further addition of individuals.

Establishing a functional seed bank collection requires an effective sampling design to capture local and rare allelic variants (Petit et al., 1998; Schoen and Brown, 2001). Gargiulo et al. (2019) investigated the genetic diversity of germplasm collections of the Millennium Seed Bank and wild-provenance populations of Taxus baccata L. using nuclear microsatellites. The allelic capture of seeds reached $86 \%$ of the alleles from wild populations, including rare and locally common variants, which is an accurate representation of the wild source.

Based on a specific sampling strategy, more than 60 target species have already been collected in Great Britain. Seed collections were made from every Forestry Commission seed zone across all target taxa. The seed zones were created according to biogeographic zones and the acting environmental conditions which may influence dispersal and gene flow (Herbert et al., 1999; Kallow and Trivedi, 2017).

An overall sampling from the whole area of distribution is however not a full guarantee of the conservation success, as it heavily depends on further ex situ management. Pinus koraiensis Siebold \& Zucc. is a nationally endangered species of China preserved in clonal seed orchards (CSO) that include provenances from the whole distribution area. Tong et al. (2020) used nine SSR markers to study the genetic diversity and population structure of the provenances in the CSO, and compared the genetic variation of maternal populations and offsprings. High genetic diversity was detected in both the maternal and progeny populations, indicating that $\mathrm{CSO}$ can preserve an adequate diversity within the ex situ gene pool. In offsprings, the genetic diversity was even higher, which was likely due to the efficient mixing of the gene pools of the mother plants. However, the primary population differentiation due to regional adaptation was missing in the new ex situ generation, and the gene pool was homogenized, causing conservation concerns. 


\section{The importance of optimal sample size}

To establish and maintain genetically and phenotypically diverse living collections, one of the most challenging tasks is to choose species-specific sample sizes for optimal ex situ conservation. If sampling is suboptimal and the number of sampled individuals is low, the resulting small populations will be exposed to genetic risks (Allendorf et al., 2013). A first theoretical minimum sample size able to capture non-rare alleles was approximated by Marshall and Brown (1975) to between 30 - 60 individuals for an optimal allelic capture. Based on this recommendation, a minimum sample size of 50 individuals per population has been commonly used by conservationists for decades (Hoban and Strand, 2015). Recent evidence however clearly suggest that the appropriate minimum sampling size differs by species, it is not predictable by genus or population structure and simplistic sampling protocols applied equally to all taxa within a genus result in unsatisfactory outcomes, thus it is time to abandon this rather rigid approach (Hoban and Schlarbaum, 2014; Hoban and Strand, 2015; Hoban, 2019; Hoban et al., 2020).

Most current-day ex situ collections have suboptimal sizes according to Hoban et al. (2020) and the root of the problem is often the ignorance, or lack of knowledge of effective population size, and consequently missampled wild populations. A molecular study based on microsatellite markers in Ceroxylon quindiuense (H. Karst.) H. Wendl., an endemic species of the cloud forests of Colombia, showed that the material from ex situ collections originated from a single wild population and exhibited low genetic diversity and a low percentage of private alleles compared to the wild population. Several alleles of the in situ populations were completely missing and there was a higher rate of full-siblings in the ex situ collection. This outcome was likely the result of a poorly planned sampling design, i.e., seed collection from only a few parents (Chacón-Vargas et al., 2019). Likewise, non-representative seed sampling and small-sized ex situ population (27 individuals compared to natural populations with more than 100 individuals), as well as differences in habitat ecology between the garden and natural populations caused low average gene diversity within populations and high genetic differentiation among populations of Loropetalum subcordatum (Benth.) Oliv., an endangered species endemic to China with high conservation priority (Li et al., 2018).

Cochlearia polonica E. Fröhlich, a narrow endemic perennial plant of Poland had only one transplanted population left in the wild. As the source material contained only five individuals, the ex situ stand exhibited very low genetic variation i.e, three unique bands out of the 11 detected with ISSR markers in the wild populations (Rucińska and Puchalski, 2011). Further major differences in genetic composition reinforced that the garden population preserved only a very limited amount of the species' genetic variability.

Other attempts were more successful at calibrating the sampling protocols, securing the long-term survival of the ex situ collections. In a study based on ISSR markers of Sinocalycanthus chinensis W.C.Cheng $\&$ S.Y.Chang. the genetic diversity metrics $(\mathrm{Na}, \mathrm{Ne}, \mathrm{h}$, and I) were not significantly different between ex situ and natural populations. This positive result was attributed to a sample size sufficient for this species, which included eight natural populations with 20 individuals from each population (Chen et al., 2013). In another collection of Leucothrinax morrisii (H.Wendl.) C. Lewis and Zona established ex situ with just 58 plants, the allelic capture was greater than $94 \%$. In this particular species, modeling exercises indicated that 15 individuals are sufficient to conserve a representative sample from species' genetic diversity (Namoff et al., 2010).

Overall, species' biogeographical and demographic history such as the frequency of reproduction events are better predictors of an optimal sampling than the number of individuals alone, but more evidence is required before emerging any generalizations. As general guiding principles, it is advisable to tailor the sampling design to species' biology, possibilities of collection maintenance, and desired characteristics of the collection (e.g., number of allele copies and type of alleles targeted). Genetic data may be used to calculate the optimal specimen number, and sampling could be improved by collecting fewer seeds per plant but from several unique maternal plants, as well as by frequent sampling from the wild populations. Generally, a sufficient minimum collection size for a species seems to be ranging between 30-200 (300) plants (Hoban and Strand, 2015; Hoban et al., 2020). 


\section{Consequences of limited space and generation time in ex situ collections}

As mentioned earlier, exact numbers necessary for establishing an effective population size are particularly difficult to ascertain and depend on species-specific mating types and reproductive strategies (Ensslin, 2011; Basey et al., 2015; Ensslin et al., 2015). Other recommendations include periodic immigrations from the wild source population, increasing (tripling) the sample size in each generation which mitigates the effect of genetic drift by mimicking natural pollen flow patterns, and controlled pollination that may assist in preventing inbreeding depression (Havens et al., 2004, 2006). Near-natural cultivation methods, which allow generation overlap and interspecific competition, help to reconstruct a species' original environment under $e x$ situ conditions and better address the challenges of ex situ populations. A study by Lauterbach et al. (2012) based on AFLP markers compared three ex situ and their source in situ populations of the endangered Silene otites (L.) Wibel in Germany. Two ex situ populations were maintained in a single-species garden bed, with regular weed control and with biennial rejuvenation, and one population was cultivated under near-natural conditions. The genetic variation in the ex situ garden-bed populations was lower than in the wild source populations and the high level of $\mathrm{F}_{\mathrm{ST}}$ value suggested a strong differentiation between the in situ and ex situ populations. The founder effect, genetic drift and inbreeding depression increased effect with the growing cultivation time in all ex situ populations. However, under near-natural conditions, the loss of genetic diversity was comparatively lower, and thus the population conservation was more successful.

The genetic risks to which small ex situ populations are exposed are exacerbated in species with short generation time especially in annuals, because a fast generation turnover results in very early manifestations of population genetic mechanisms (Schaal and Leverich, 2004). In a study of the short-lived Cynoglossum officinale L. based on nuclear microsatellite markers, four garden populations had almost zero genetic diversity that was correlated with cultivation time in the botanical garden. This was likely due to long-term genetic drift that may have increased fast with the number of generations. The mixed mating system with a high selfing rate (up to 70\%) of the species could have additionally contributed to the strong genetic drift observed (Vrieling et al., 1999; Ensslin et al., 2011). Another study of five annual species of arable fields (Anagallis arvensis L., Anagallis foemina Mill., Bupleurum rotundifolium L., Consolida regalis L., Nigella arvensis L.) assessed the impact of ex situ cultivation on the genetic diversity and composition based on RAPD markers (Brütting et al., 2012). In four out of five annual species, ex situ collections exhibited low levels of genetic diversity, an underrepresented allele structure and they even missed common alleles. Species that showed lower genetic diversity ex situ were mostly short-lived and frequently self-pollinating (Brütting et al., 2012). These observations underscore the necessity to tailor not just the sampling design in the wild, but also the long-term ex situ maintenance plans to species' life form and breeding system (Schaal and Leverich, 2004).

\section{The importance of ex situ planting design}

Pollen dispersal is one of the main mechanisms of gene flow, which influences the long-term survival of populations. The often higher than the usual density of plants in collections inevitably alters the natural pollen dispersal distances, with important genetic consequences that need careful examination. While some in situ populations may experience biparental inbreeding due to small size and limited gene flow, the corresponding ex situ populations planted in high densities may overcome both challenges and have a lower rate of crosses between relatives. Dipteryx alata Vogel is an evergreen tree and an important biological and agricultural resource in the Brazilian Cerrado. The species is vulnerable due to intensive agricultural use and therefore its ex situ conservation has high priority (World Conservation Monitoring Centre, 1998; IUCN, 2020). The genetic diversity and the level of polymorphism of the germplasm collection had higher values than the in situ populations because the germplasm collection was established from different populations within a region (Corrêa et al., 2000). Thus, the ex situ conditions preserved a larger number of alleles across generations. However, paternity correlation and pollen dispersal distance were lower in ex situ than under natural conditions, due to the higher density of individuals compared to the natural populations that reduced the pollinator traveling distance (Guimarães et al., 2019). 
High ex situ individual densities often cause inbreeding, and correct planting design and species-specific spatial structuring in transplants are needed to alleviate the risk of inbreeding. Aguiar et al. (2019) studied Balfourodendron riedelianum (Engl.) Engl., an endangered tree of the Atlantic Forest. Ex situ seedlings and adult trees were genotyped with microsatellite markers and indicated that the effective population size was adequate for short-term conservation. Analyses of pollen dispersal distance showed an isolation-by-distance (IBD) pattern, likely due to the high population density in the trial population and enhanced pollination due to shorter flying distances of the pollinators. Seedlings were predominantly outcrossed (93-96.2\%), but selfing (3.8-7\%) and mating between relatives (20-28.1\%) resulted in biparental inbred seeds and seedlings with lower genetic diversity. This was most probably the consequence of the planting design, as provenances were grouped in plots within blocks (maternal families) and individuals of the same provenances were located in close proximity (Aguiar et al., 2019).

Comparative genetic studies between in situ and ex situ conditions are thus useful tools for quantifying cross-pollination rates and pollen dispersal distance between populations, as well as for detecting potential shortages of animal pollinators under ex situ conditions (Allendorf, 2013; Ellstrand, 2014).

\section{The consequence of unwanted gene flow within ex situ collections}

Unwanted gene flow can undermine the genetic integrity of ex situ collections, causing hybridization through cross-pollination with different species and introgression between different populations of the same species (garden accessions or garden and wild crosses) (Maunder et al., 2004; Ensslin and Godefroid, 2019).

Interspecific hybrids may exhibit superior qualities compared to their parents, which may further jeopardize the species' genetic integrity. Sinojackia xylocarpa Hu is a Chinese endemic tree extinct in the wild (Yao et al., 2005), therefore its reintroduction in the wild would be critical. The plant is at great hybridization risk in the Wuhan Botanic Garden due to the presence of Sinojackia rehderiana Hu, a congener species. A study based on microsatellites revealed that $32.7 \%$ of the collected seeds were hybrids, and the paternity of 93 out of 249 seedlings was assigned to $S$. rehderiana. Hybrids had longer pollen dispersal distances than their parents. Avoiding extensive hybridization would require the establishment of a buffer zone, controlled pollination and testing the seeds before reintroduction (Zhang et al., 2010).

Controlled inter-specific crosses can evaluate the chance of possible hybridization events and their negative outcomes. Lozada-Gobilard et al. (2020) performed controlled inter-specific crosses between Minuartia smejkalii M. Dvoráková (endemic to the Czech Republic) and its congener Minuartia caespitosa (Willd.) Degen. The results confirmed that the two species may hybridize and hybrid individuals had higher germination rates of the viable seeds, a higher number of flowers and also higher dispersal potential.

Hybrids can outcompete the original endangered species upon repatriation, therefore a greater caution is recommended before any restoration attempt in the wild. In studies with Plantago lanceolata L. and Lotus corniculatus L., Schröder and Prasse (2013) observed that hybrids from cultivated varieties outcompeted wild sources due to advantageous germination traits. But it is often difficult to disentangle the effects of cultivation on species' life history from the effects of unwanted gene flow. Schröder and Prasse (2013) also observed that cultivated individuals germinated faster and were more abundant than the wild sources, and it was not just the hybridization per se that had a great impact on species' life-history traits, but cultivation also.

Genetic diversity studies revealed important aspects related to ex situ gene stocks established in garden collections all over the world. Rich evidence has accumulated about the current state of the existing ex situ collections, as well as about the main forces that shape the genetic make-up of species maintained in ex situ collections. These experiences represent a strong handrail for future conservation efforts. In Table 1, we summarize a list of case studies performed to reveal differences in the genetic make-up of populations and fundamental successful conservation activities. 
Table 1. List of case studies showing main genetic markers associated with comparative analyses of ex situ collections and in situ stands of plant species

\begin{tabular}{|c|c|c|c|}
\hline Examined taxon & $\begin{array}{c}\text { Markers used to } \\
\text { characterize gene stock }\end{array}$ & Main conclusions & References \\
\hline \multicolumn{4}{|c|}{ Case studies conducted on trees } \\
\hline $\begin{array}{l}\text { Vatica guangxiensis } \\
\text { S.L. Mo }\end{array}$ & RAPD markers & $\begin{array}{l}\text { Intermediate genetic variation, } \\
\text { that showed to be representative } \\
\text { at the species level. }\end{array}$ & Li et al. (2002) \\
\hline $\begin{array}{l}\text { Leucothrinax } \\
\text { morrisii }(\mathrm{H} . \text { Wendl.) } \\
\text { C. Lewis \& Zona } \\
\end{array}$ & ISSR markers & $\begin{array}{l}\text { Similar genetic diversity and low } \\
\text { genetic distance between ex situ } \\
\text { and in situ populations. }\end{array}$ & Namoff et al. (2010) \\
\hline $\begin{array}{l}\text { Sinojackia xylocarpa } \\
\mathrm{Hu} \text { and } \\
\text { Sinojackia } \\
\text { rehderiana } \mathrm{Hu}\end{array}$ & Microsatellite markers & $\begin{array}{c}\text { Extensive hybridization between } \\
\text { the two species in garden } \\
\text { conditions. }\end{array}$ & Zhang et al. (2010). \\
\hline $\begin{array}{l}\text { Zelkova carpinifolia } \\
\text { (Pall.) K. Koch } \\
\text { and } \\
\text { Zelkova abelicea } \\
\text { (Lam.) Boiss. }\end{array}$ & $\begin{array}{l}\text { cpDNA spacer (trnH- } \\
\text { psbA) and cpDNA } \\
\text { intron (trnL) }\end{array}$ & $\begin{array}{l}\text { New haplotypes and genetic } \\
\text { representativeness in ex situ } \\
\text { collection. } \\
\text { Low number of haplotypes } \\
\text { represented in ex situ garden } \\
\text { collections. }\end{array}$ & Christe et al. (2014) \\
\hline $\begin{array}{l}\text { Taxus yunnanensis } \\
\text { W. C. Cheng \& L. } \\
\text { K. Fu }\end{array}$ & Microsatellite markers & $\begin{array}{l}\text { Lower genetic diversity in ex situ } \\
\text { collections, but } 23 \text { unique alleles } \\
\text { preserved. }\end{array}$ & $\begin{array}{l}\text { Miao et al. } \\
\quad(2015)\end{array}$ \\
\hline $\begin{array}{l}\text { Balfourodendron } \\
\text { riedelianum (Engl.) } \\
\text { Engl. }\end{array}$ & Microsatellite markers & $\begin{array}{l}\text { Lower pollen dispersal distance, } \\
\text { biparental inbred seeds and } \\
\text { seedlings in ex situ collection. }\end{array}$ & Aguiar et al. (2019) \\
\hline $\begin{array}{l}\text { Ceroxylon } \\
\text { quindiuense } \\
\text { (H.Karst.) } \\
\text { H.Wendl. }\end{array}$ & Microsatellite markers & $\begin{array}{l}\text { Lower genetic diversity, higher } \\
\text { rate of full-siblings in ex situ. }\end{array}$ & Chacón-Vargas et al. (2019) \\
\hline Dipteryx alata Vogel & Microsatellite markers & $\begin{array}{l}\text { Higher genetic diversity in } e x \\
\text { situ, but lower paternity } \\
\text { correlation and decreased pollen } \\
\text { dispersal distance. }\end{array}$ & Guimarães et al. (2019) \\
\hline Taxus baccata L. & Microsatellite markers & $\begin{array}{l}\text { Allelic capture, including rare } \\
\text { and locally common alleles are } \\
\text { representative in ex situ seed } \\
\text { bank collection. }\end{array}$ & Gargiulo et al. (2019) \\
\hline $\begin{array}{l}\text { Pinus koraiensis } \\
\text { Siebold \& Zucc. }\end{array}$ & SSR markers & $\begin{array}{c}\text { Higher genetic diversity in the } \\
\text { progeny due to gene pool } \\
\text { mixing. }\end{array}$ & Tong et al. (2020) \\
\hline \multicolumn{4}{|c|}{ Case studies conducted on shrubs } \\
\hline $\begin{array}{l}\text { Berberidopsis } \\
\text { corallina Hook.f. }\end{array}$ & RAPD markers & $\begin{array}{l}\text { Representative genetic diversity } \\
\text { and a high number of genotypes } \\
\text { preserved in ex situ collection. }\end{array}$ & Etisham-Ul-Haq et al. (2001) \\
\hline $\begin{array}{l}\text { Sinocalycanthus } \\
\text { chinensis W. C. } \\
\text { Cheng \& S. Y. } \\
\text { Chang. }\end{array}$ & ISSR markers & $\begin{array}{l}\text { Representative seed sampling } \\
\text { resulted in similar genetic } \\
\text { diversity between in situ and } e x \\
\text { situ populations. }\end{array}$ & Chen et al. (2013) \\
\hline
\end{tabular}


Kovács Zs. et al. (2021). Not Bot Horti Agrobo 49(2):12334

\begin{tabular}{|c|c|c|c|}
\hline $\begin{array}{l}\text { Loropetalum } \\
\text { subcordatum } \\
\text { (Benth.) Oliv. }\end{array}$ & SRAP markers & $\begin{array}{c}\text { Strong population } \\
\text { differentiation and lower level of } \\
\text { genetic diversity in ex situ } \\
\text { population. }\end{array}$ & Li et al. (2018) \\
\hline \multicolumn{4}{|c|}{ Case studies conducted on herbaceous species } \\
\hline $\begin{array}{l}\text { Cochlearia polonica } \\
\text { E. Fröhlich }\end{array}$ & ISSR markers & $\begin{array}{l}\text { Reduced genetic variability and } \\
\text { high level of differentiation } \\
\text { between in situ and ex situ } \\
\text { populations. }\end{array}$ & $\begin{array}{l}\text { Rucińska and Puchalski } \\
\qquad(2011)\end{array}$ \\
\hline $\begin{array}{l}\text { Cynoglossum } \\
\text { officinale } \mathrm{L} .\end{array}$ & Microsatellite markers & $\begin{array}{c}\text { Genetic diversity reduced with } \\
\text { the cultivation time. }\end{array}$ & Ensslin et al. (2011) \\
\hline $\begin{array}{l}\text { Silene otites (L.) } \\
\text { Wibel }\end{array}$ & AFLP markers & $\begin{array}{l}\text { Reduced genetic variability and } \\
\text { high level of differentiation in } e x \\
\text { situ populations. }\end{array}$ & Lauterbach et al. (2012) \\
\hline $\begin{array}{l}\text { Anagallis arvensis } \\
\text { L., Anagallis } \\
\text { foemina Mill., } \\
\text { Bupleurum } \\
\text { rotundifolium L., } \\
\text { Consolida regalis L., } \\
\text { Nigella arvensis L. }\end{array}$ & RAPD markers & $\begin{array}{c}\text { Lower genetic diversity and } \\
\text { strong differentiation of ex situ } \\
\text { collections. }\end{array}$ & Brütting et al. (2012) \\
\hline $\begin{array}{l}\text { Plantago lanceolata } \\
\text { L. and Lotus } \\
\text { corniculatus L. }\end{array}$ & - & $\begin{array}{l}\text { Faster and more abundant } \\
\text { germination in cultivated plants } \\
\text { and hybrids. }\end{array}$ & Schröder and Prasse (2013) \\
\hline $\begin{array}{l}\text { Zizania texana } \\
\text { Hitchc. }\end{array}$ & Microsatellite markers & $\begin{array}{l}\text { Lower allelic diversity in ex situ } \\
\text { collections. }\end{array}$ & Wilson et al. (2017) \\
\hline $\begin{array}{l}\text { Minuartia smejkalii } \\
\text { Dvoráková and } \\
\text { Minuartia } \\
\text { caespitosa (Willd.) } \\
\text { Degen }\end{array}$ & - & $\begin{array}{l}\text { Hybridization potential between } \\
\text { the two species. }\end{array}$ & Lozada-Gobilard et al. (2020) \\
\hline
\end{tabular}

\section{Trait-based studies in ex situ populations}

While interest in the genetic representation of ex situ collections has increased in the recent decades, the trait-based shifts such as fitness decline or changes caused by maladaptation have received less attention (Ensslin et al., 2015). The genetic drift experienced by small and isolated plant populations has a visible impact on the phenotype and it may result in the decline of main fitness parameters in ex situ stands as well (Ellstrand and Elam, 1993). Important shifts in a life-history trait can occur when wild plants are introduced into novel environments such as botanic gardens or arboreta. In this case, plants are exposed to new selection pressures, which may result in evolutionary adaptation over time. In gardens, intensive horticultural care carries high risks of unconscious selection. Gardeners protect plants by daily watering, manuring or treatment against pathogens and with time, ex situ collection may lose the ability to tolerate less favourable environmental conditions. At the same time, selection pressures such as drought stress or lack of nutrients continue to shape populations in the wild causing many adaptive changes that remain uncaptured in ex situ stands. In addition, under ex situ conditions the weeding process eliminates the interspecific competition pressure, and individuals may lose their ability to face competition. If changes incurred by plants are maladaptive, they can cause the failure of the repatriation process (Ensslin and Godefroid, 2019). Therefore, tracking phenotypic changes over time in garden populations is of great importance for conservation (Husband and Campbell, 2004; Ensslin and Godefroid, 2019). 


\section{Trait shifts in novel environments}

Ex situ cultivation may have a negative impact on fitness and other phenological traits. In a study of four native wild species (Carlina vulgaris L., Corynephorus canescens P. Beauv., Jasione montana L., Melilotus officinalis L.) ex situ plants clearly showed lower fitness performance than their wild source relatives (Ensslin et al., 2015). In the case of Carlina vulgaris the different years of cultivation (3 to 31 years) affected negatively the number of flowering stems. The regeneration method (artificial vs. natural propagation) did not influence the fitness of ex situ plants, and thus the fitness decline was caused by genetic drift under garden conditions rather than by selection.

Life-history traits such as seed traits can experience important changes in germplasm collections. Seed germination rates can increase in germplasms as the result of unconscious or non-intentional selection by gardeners, who tend to plant out only the early germinating seedlings (Ensslin et al., 2011; Ensslin, 2019). In a study of Cynoglossum officinale L. populations, both in situ and ex situ stands had similar seed production, but the ex situ stand, which had lower diversity, had lower mean seed mass and significantly higher germination percentage (Ensslin et al., 2011). Ensslin et al. (2018) studied the germination characteristics of 72 species. Across all species, ex situ cultivated plants exhibited higher germination percentages and lower dormancy index compared to their wild sources. However, differences decreased with a longer seed storage time as a result of seed aging.

Life history traits connected with seed dormancy patterns can be used to detect selection pressure on garden populations. In a study by Ensslin et al. (2018), plant life span explained the differences in seed dormancy between wild and ex situ populations. In 22 short-lived plant species, seed dormancy loss and increased germination ex situ were remarkably stronger compared to perennial species that were more tolerant to dormancy loss. In short-lived species characterized by fast generation turnover, regeneration via seeds is a critical step in conservation. In the case of these species, keeping seeds in cold storage and regenerating them only for immediate use is the recommended practice (Ensslin et al., 2018). Species' life history may further influence changes in germination characteristics, growth and phenology. Rauschkolb et al. (2019) investigated the influence of cultivation on trait differentiation in three threatened plant species (Trifolium spadiceum L., Sisymbrium austriacum Jacq., Bromus grossus Desf. ex DC.) and detected species-specific changes in lifehistory strategies associated with reduced performance of ex situ individuals. The differentiation happened rapidly, due to relaxed selection, genetic drift, inbreeding depression and fast adaptation to garden conditions.

Shifts in morphological traits under ex situ conditions can occur even in relatively short periods. Solberg et al. (2015) conducted an experiment on Trifolium pratense L. in in situ and ex situ populations, measuring 13 morphological and phenological traits. Four of the examined traits changed significantly within a single generation. Interestingly, the direction of changes shifted toward individuals that were similar to the commercial cultivars. The "cultivar type" was taller and larger than the wild type and had higher seed production. The increased frequency of genes associated with the morphology of the cultivars could have occurred due to the addition of genes from garden cultivars during regeneration or as a result of selection (Solberg et al., 2015).

One of the environmental triggers of trait shifts is the increased light pollution in ex situ conditions, which can have a great impact on plant species' survival and can hamper conservation efforts in botanic gardens and arboreta. Peregrym et al. (2019) studied the effects of artificial light at night (ALAN) on living collections from Central, Southern and Eastern Europe. They reported a very high level of light pollution in this region and it is possible that plants conserved ex situ change their flowering phenology, growth form and resource allocation in response to increased light availability. Herbivores and pollinators also shifted their physiology, behaviour and ecology (for instance nocturnal pollinators visit plants less frequently), which can lead to decreased fruit production and seed productivity failure (Bennie et al., 2016; Peregrym et al., 2019). The breadth of adaptive changes triggered by artificial lightening is far from being well-investigated and more research is needed to understand their effects on ex situ collections. 
Differences in habitat conditions can influence trait shifts in a variety of ways. For instance, differences in soil water regimes and maintenance level can have a fast, significant impact on morpho-phenological characteristics of the ex situ individuals. Plantago maxima Juss. ex Jacq. is a strictly protected species of Hungary, therefore the establishment and evaluation of the ex situ collection is extremely important to ensure the long-term preservation. Ex situ flowchart was designed to start a successful $e_{X}$ situ conservation of the species (Figure 1). Three stands were set up in a near-natural habitat (mesophilic fen meadow) in the Soroksár Botanical Garden, and two others were established in a perennial bed with regular weed control and frequent watering. Two years after planting, individuals from the fen meadow showed the best results: plants developed properly, peroxidase enzyme activity indicative of stress response was low and the survival rate was the highest. However only the individuals under horticultural maintenance flowered in the year of planting, and also the number of leaves significantly exceeded the ones in the meadow. This result can be due to horticultural care and lack of competition linked to weeding. Even slight differences between ex situ habitats can help evaluate the habitat preference of a species, and at the same time substantiate the success of repatriation by guiding the choice of the appropriate habitat type in the field (Kovács et al., 2019).

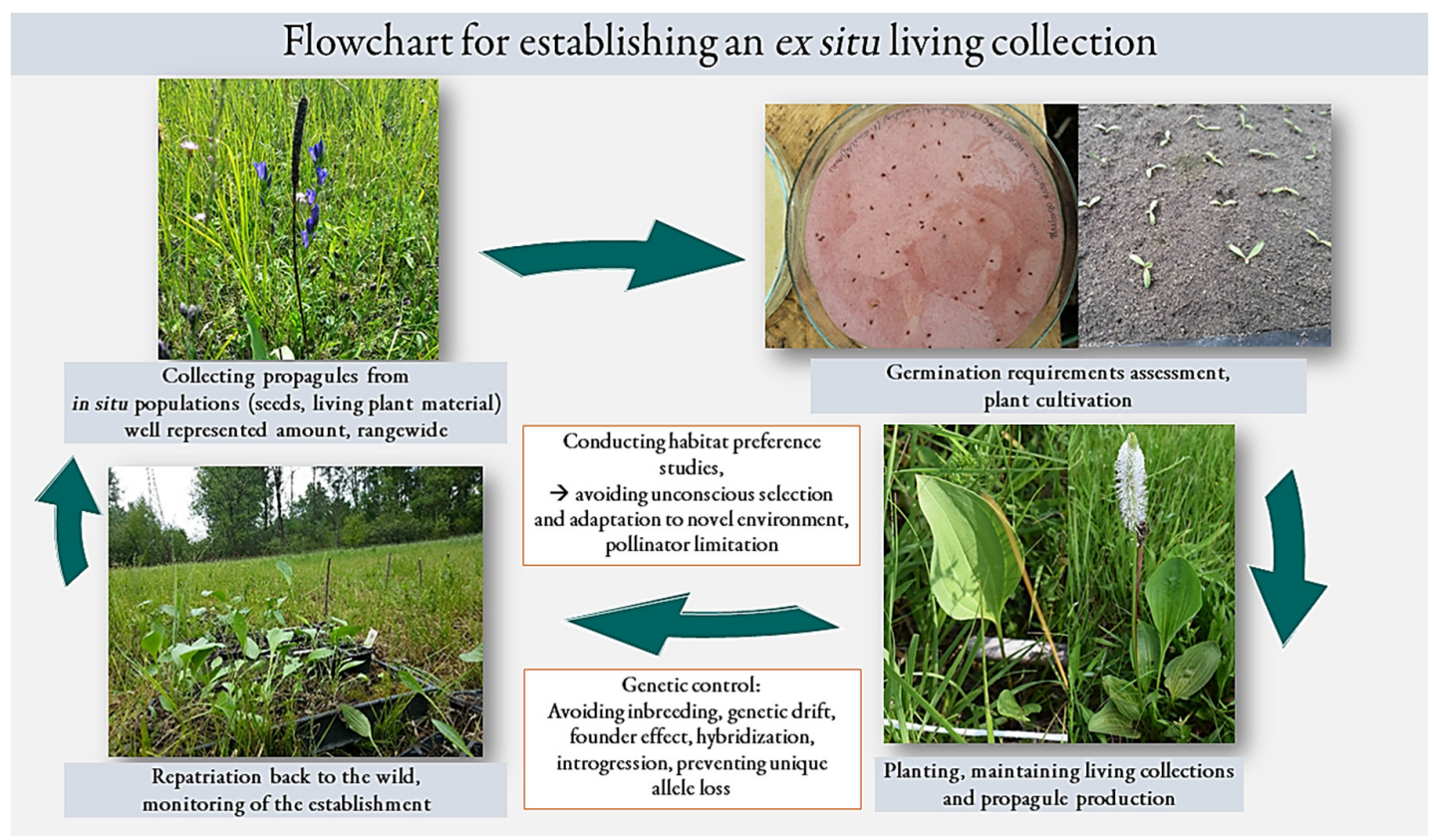

Figure 1. Flowchart for the establishment of the living collection of Plantago maxima and the acting forces on which special attention is required

Habitat differences can affect the internal content of plants such as nutrient levels. Marler and Lindstrom (2020) compared the leaf nutrient content of Cycas micronesica K.D. Hill and Cycas nongnoochiae K.D. Hill. between in situ and ex situ locations and observed higher macronutrient levels under garden conditions. Differences between the soil nutrient content of the sites did not explain the discrepancy, in turn, it was likely influenced by the growing environment.

Individuals transferred from the wild into garden conditions may undergo severe stress. Valeriana wallichii DC. is an important medicinal plant and therefore possible biochemical composition shifts in ex situ collections are important to study. Asgher et al. (2020) revealed severe stress in the ex situ stand after three years of maintenance in Lead Botanical Garden of the Department of Botany, BGSBU Rajouri. Photosynthetic and growth attributes decreased, prolin, ornithine aminotransferase, pyrroline-5-carboxylate reductase increased, and higher reactive oxygen species (ROS) accumulation indicated oxidative stress. These changes concurred with better reproductive attributes (for instance better germination ability) ex situ due to better 
pollinator availability. The study shows a clear adaptive mechanism to the novel environment, which can be due to different habitat conditions but also to the introduction of selected chemical phenotypes into ex situ collections.

Cultivation for a longer time can at the same time negatively influence stress response. Ensslin and Godefroid (2020) conducted a multi-species experiment, where they found reduced trait variability (germination rate, biomass and leaf length) and a slight reduction of response to drought stress. The change was greater in drought-tolerant than drought-intolerant species, which was due to greater environmental differences during cultivation relative to the source habitats. Near-natural habitat conditions are therefore recommended to prevent the reduction of species' evolutionary potential, which could jeopardize its ability to survive following reintroduction.

\section{Changes driven by pollination and pollinator limitation}

Pollination and seed dispersal are important indicatives of plant reproduction success. Lack of pollinators and seed dispersers under garden conditions can lead to the decline of fitness and diversity, and negatively influence the conservation success (Gong et al., 1998, Biesmeijer, 2006). Tang et al. (2019) studied the pollination biology of four threatened species endemic to China (Hibiscus aridicola J. Anthony, Amorphophallus albus P.Y. Liu \& J.F. Chen, Stemona parviflora C.H. Wright and Stemona japonica (Blume) Miq.). The study showed a reduced number of pollinators or no pollinators at all under garden conditions, which resulted in fruit set failure or a strong decrease in seed yield. Amorphophallus albus and the two Stemona species were self-incompatible, which increased the risk of extinction in garden conditions due to the absence of natural pollinators (Biesmeijer, 2006; Tang et al., 2019).

Another study examined two ex situ populations of the partially self-compatible outcrosser Iris ensata Thunb. which has a disjunct distribution in East Asia (Zhao et al., 2000). The two ex situ populations, located at relatively low elevations, initiated earlier flowering and fruit set compared to native populations. However, pollinator visits were less frequent, and no pollinator was observed in one of the ex situ populations. The consequence was inbreeding depression that limited seed set and germination, but it did not affect seedling survival (Xiao et al., 2019).

In Table 2 there we present a list of case studies on trait changes in ex situ collections.

Table 2. List of case studies showing main traits analysed comparatively between ex situ collections and in situ stands

\begin{tabular}{|c|c|c|}
\hline Examined taxon & Main conclusions & References \\
\hline \multicolumn{3}{|c|}{ Case studies conducted on trees and shrubs } \\
\hline $\begin{array}{l}\text { Cycas micronesica K.D. Hill and Cycas } \\
\text { nongnoochiae K.D. Hill. }\end{array}$ & $\begin{array}{l}\text { Higher macronutrient content in } \\
\qquad \text { ex situ. }\end{array}$ & Marler and Lindstrom (2020) \\
\hline $\begin{array}{l}\text { Hibiscus aridicola J. Anthony, } \\
\text { Stemona parviflora C.H. Wright, Stemona } \\
\text { japonica (Blume) Miq. }\end{array}$ & $\begin{array}{c}\text { Reduced number of } \\
\text { pollinators/no pollinators - fruit } \\
\text { set decrease and failure. }\end{array}$ & Tang et al. (2019) \\
\hline \multicolumn{3}{|c|}{ Case studies conducted on herbaceous species } \\
\hline $\begin{array}{l}\text { Carlina vulgaris L., Corynephorus } \\
\text { canescens P. Beauv., Jasione montana L., } \\
\text { Melilotus officinalis L. }\end{array}$ & $\begin{array}{l}\text { Fitness decline in ex situ } \\
\text { collection. }\end{array}$ & Ensslin et al. (2015) \\
\hline Trifolium pratense L. & $\begin{array}{l}\text { Rapid morphological trait shift in } \\
\text { ex situ. }\end{array}$ & Solberg et al. (2015) \\
\hline Cynoglossum officinale $\mathrm{L}$. & $\begin{array}{l}\text { Changed seed mass, increase in } \\
\text { germination percentage in ex situ } \\
\text { collection. }\end{array}$ & Ensslin et al. (2011) \\
\hline
\end{tabular}


Kovács Zs. et al. (2021). Not Bot Horti Agrobo 49(2):12334

\begin{tabular}{|c|c|c|}
\hline $\begin{array}{l}72 \text { short-lived or long-lived herbaceous } \\
\text { species with orthodox seeds }\end{array}$ & $\begin{array}{l}\text { Short-lived plant species were } \\
\text { vulnerable to the seed dormancy } \\
\text { loss and germination increase in } \\
\text { ex situ. }\end{array}$ & Ensslin et al. (2018) \\
\hline Plantago maxima Juss. ex Jacq. & $\begin{array}{l}\text { Rapid morpho-phenological } \\
\text { response to different habitat types } \\
\text { and level of maintenance under } e x \\
\text { situ condition. }\end{array}$ & Kovács et al. (2019) \\
\hline $\begin{array}{l}\text { Trifolium spadiceum L., } \\
\text { Sisymbrium austriacum Jacq. } \\
\text { Bromus grossus Desf. ex DC. \& A.Camus }\end{array}$ & $\begin{array}{l}\text { Rapid changes of life-history trait } \\
\text { in ex situ. }\end{array}$ & Rauschkolb et al. (2019) \\
\hline $\begin{array}{l}\text { Amorphophallus albus P.Y. Liu \& J.F. } \\
\text { Chen }\end{array}$ & $\begin{array}{l}\text { Reduced number of } \\
\text { pollinators/no pollinators - fruit } \\
\text { set decrease and failure. }\end{array}$ & Tang et al. (2019) \\
\hline Living collections & $\begin{array}{l}\text { Artificial light at night (ALAN) } \\
\text { produced shifts in flowering } \\
\text { phenology, growth form and } \\
\text { resource allocation. }\end{array}$ & Peregrym et al. (2019) \\
\hline Iris ensata Thunb. & $\begin{array}{c}\text { Changed phenology, pollinator } \\
\text { limitations. }\end{array}$ & Xiao et al. (2019) \\
\hline $\begin{array}{l}12 \text { drought-tolerant or drought-intolerant } \\
\text { herbaceous perennial species }\end{array}$ & $\begin{array}{l}\text { Reduced trait variability and } \\
\text { decreased response to drought } \\
\text { stress in cultivated species. } \\
\text { Increased resource acquisition } \\
\text { strategy in drought-tolerant } \\
\text { species. }\end{array}$ & Ensslin and Godefroid (2020) \\
\hline Valeriana wallichii DC. & $\begin{array}{l}\text { Increased stress related } \\
\text { biochemical components and } \\
\text { reproductive attributes. } \\
\text { Decreased photosynthetic and } \\
\text { growth attributes in ex situ. }\end{array}$ & Asgher et al. (2020) \\
\hline
\end{tabular}

\section{Attempts to regenerate and repatriate ex situ generations}

One of the most important and crucial last steps in the ex situ conservation is the reintroduction of rare plant species to their natural habitats. The repatriation and reintroduction techniques are important conservation actions that help restoring the original population of endangered taxa and facilitates the reconstruction of the natural community structure (Haskins and Pence, 2012). Plant propagules (for example seedlings, cuttings or in vitro propagated plants) of ex situ origin are not fully adapted to conditions in their original natural habitat, but environmental differences can trigger the acclimatization needed for the successful reintroduction process (Haskins and Pence, 2012).

Perhaps the biggest challenge in the repatriation attempts is represented by individuals propagated in vitro. In a study of three Dianthus species (D. callizonus Schott \& Kotschy, D. glacialis Haenke ssp. gelidus (Schott, Nyman \& Kotschy) Tutin and D. spiculifolius Schur) Cristea et al. (2013) compared the acclimatization of wild plants and of plantlets propagated in vitro when replanted in ex situ conditions. $D$. spiculifolius had the best ability to acclimatize, likely due to the climatic and phytosociological conditions similar to the natural habitats secured for the species in the botanical garden. Plantlets propagated in vitro adapted and survived much better in outdoor conditions than the replanted wild individuals, but the 
advantages of in vitro propagation unfold with longer-term monitoring of the somaclonal variability necessary for genetically certified gene stock conservation.

Dianthus diutinus Kit. is an endemic species of the Pannonian biogeographic region. Species' populations can only be found in the region between the Danube and Tisza rivers in Central Hungary. The Botanical Garden of the University of Szeged carried out a population genetic survey of the wild population to secure the success of the collection of the ex situ plant material. Ex situ plants were grown in conditions similar to the in situ environment. Following repatriation, soil seed bank and seed biology, population genetic study with RAPD markers, and habitat preference were examined to control the success of repatriation. The high survival rate and further in situ reproduction supported the effective conservation efforts (Németh and Makra, 2011).

In another case study in Finland, a natural population of Rubus humulifolius C.A.Mey. has gone through a severe decline and it was destroyed during construction work. A few individuals survived in a private cottage garden; therefore the in vitro propagation of the species was the single way for recovery. The in vitro propagated plants were introduced into several Finnish botanical gardens. The ex situ collections had low seed production, likely due to bottleneck or inbreeding depression, which anticipated possible recovery failure in the long run. Nonetheless, the reintroduced population was successful in the wild (Hyvärinen, 2020). Also, a successful cryopreservation protocol for micropropagated individuals were developed, to enable a long-term conservation of the germplasm. The regenerated plants were successfully transferred into common garden, which is an important step for future restoration (Edesi et al. 2020).

Successful repatriation attempts are most easily guided by analyses of different population traits. Salix lapponum L. is a relict species of eastern Poland. Pogorzelec et al. (2020) conducted habitat quality research and comparatively examined four plots representing possible suitable habitats for the reintroduction process. The study assessed the survival rate, the number of flowering plants, mean leaf length and width, and mean plant height of plants outplanted from the ex situ collection. Significant differences in functional traits were detected depending on the habitat conditions, and survival rates finally guided the successful reintroduction of the species.

\section{Conclusions}

The number of ex situ collections has increased greatly in recent years intending to achieve GSPC targets. The acceleration of published case studies provided a high amount of data on factors that influence the long-term success of conservation and the effectiveness of ex situ cultivation in garden conditions. Knowledge harnessed from these case studies is extremely important for supporting the optimal maintenance and management of wild resources in botanical gardens.

Overall, the genetic representativeness of the living collections was generally low. Even though many new recommendations regarding ex situ conservation have been made, major knowledge gaps still remain. For instance, despite the importance of pollinators' presence or absence, only a few studies have focused on this topic. Little is known on the effects of hybridization, which represents a great risk within the garden ex situ populations and may end in the shift of genetic variation compared the to source populations.

Finally, changes in the environmental factors linked to human activity, for example, artificial light, is not thoroughly researched. Even though trait changes linked to human activity have a serious impact on ex situ garden collections, the direction of these changes is less known. A considerable number of studies are focusing on the genetic representativeness of the ex situ populations, but in-depth studies of morpho-phenological trait shifts, especially of threatened species, are still lacking. 


\section{Authors' Contributions}

ZSK designed the manuscript, wrote and authored most of the manuscript; $\mathrm{MH}$ authored part of the manuscript and reviewed drafts of the paper and made corrections; PCS and AMCS reviewed drafts of the paper and corrected the manuscript. All authors read and approved the final manuscript.

\section{Acknowledgements}

We are indebted to the anonymous reviewers for their comments and suggestions. This research received no specific grant from any funding agency in the public, commercial, or not-for-profit sectors.

\section{Conflict of Interests}

The authors declare that there are no conflicts of interest related to this article.

\section{References}

Aguiar BI, Freitas MLM, Zannato AS, Tambarussi EV, Moraes MLT, Ambrosano MN, ... Sebbenn AM (2020). The effects of pollen dispersal and mating pattern on inbreeding depression and hybrid vigor in Balfourodendron riedelianum (Engl.) Engl. (Rutaceae). Conservation Genetics 21:305-317. https://doi.org/10.1007/s10592-020-01250-0

Allendorf FW, Luikart G, Aitken SN (2013). Genetics and the conservation of populations. Wiley-Blackwell Publishing (2nd ed), Oxford, UK.

Asgher M, Verma S, Khan NA, Vyas D, Kumari P, Rashid S, ... Ahmad P (2020). Physiological, biochemical and reproductive studies on Valeriana wallichii, a critically endangered medicinal plant of the Himalayan region grown under in-situ and ex-situ conditions. Plants 9(2):131. https://doi.org/10.3390/plants9020131

Basey AC, Fant JB, Kramer AT (2015). Producing native plant materials for restoration: 10 rules to collect and maintain genetic diversity. Native Plants Journal 16(1):37-53. http://npj.uwpress.org/cgi/doi/10.3368/npj.16.1.37

Bennie J, Davies TW, Cruse D, Gaston KJ (2016). Ecological effects of artificial light at night on wild plants. Journal of Ecology 104:611-620. https://doi.org/10.1111/1365-2745.12551

Biesmeijer JC (2006). Parallel declines in pollinators and insect-pollinated plants in Britain and the Netherlands. Science 313(5785):351-354. https://doi.org/10.1126/science.1127863

Brown ADH, Briggs JD (1991). Sampling strategies for genetic variation in ex situ collections of endangered plant species. In: Falk DA, Holsinger KE (Eds). Genetics and Conservation of Rare Plants. Oxford University Press, New York pp 99-122.

Brütting C, Hensen I, Wesche K (2012). Ex situ cultivation affects genetic structure and diversity in arable plants. Plant Biology 15(3):505-513. https://doi.org/10.1111/j.1438-8677.2012.00655.x

Chacón-Vargas K, García-Merchán VH, Sanín MJ (2019). From keystone species to conservation: conservation genetics of wax palm Ceroxylon quindiuense in the largest wild populations of Colombia and selected neighbouring ex situ plant collections. Biodiversity and Conservation 29:283-302. https://doi.org/10.1007/s10531-019-01882$W$

Chen XB, Tian Q, Zhang QX (2013). Genetic diversity and ex situ conservation of Sinocalycanthus chinensis. Acta Horticulturae 977:253-257. https://doi.org/10.17660/ActaHortic.2013.977.29

Christe C, Kozlowski G, Frey D, Fazan L, Bétrisey S, Pirintsos S, ... Naciri Y (2014). Do living ex situ collections capture the genetic variation of wild populations? A molecular analysis of two relict tree species, Zelkova abelica and Zelkova carpinifolia. Biodiversity and Conservation 23(12):2945-2959. https://doi.org/10.1007/s10531-0140756-9 
Cochrane A (2004). Western Australia's ex situ program for threatened species: a model integrated strategy for conservation. In: Guerrant EO, Havens K, Maunder M (Eds). EX situ Plant Conservation: Supporting Species Survival in the Wild. Island Press, Washington, DC pp 231-285.

Corrêa GDC, Da Rocha MR, Naves RV (2000). Germinação de sementes e emergência de plântulas de baru (Dipteryx alata Vog.) nos cerrados do Estado de Goiás [Seed germination and emergence of baru seedlings (Dipteryx alata Vog.) close to the State of Goiás] Pesquisa Agropecuária Tropical 30:17-23. https://doi.org/10.5216/pat.v30i2.2580

Cristea V, Jarda L, Holobiuc I (2013). Ex situ conservation of three endemic and/or endangered Dianthus species. Notulae Botanicae Horti Agrobotanici Cluj-Napoca 41(1):73-78. https://doi.org/10.15835/nbha4119110

Edesi J, Tolonen J, Ruotsalainen AL, Aspi J, Häggman H (2020). Cryopreservation enables long-term conservation of critically endangered species Rubus humulifolius. Biodiversity and Conservation 29:303-314 https://doi.org/10.1007/s10531-019-01883-9

Ellstrand NC (2014). Is gene flow the most important evolutionary force in plants? American Journal of Botany 101(5):737-753. https://doi.org/10.3732/ajb.1400024

Ellstrand NC, Elam DR (1993). Population genetic consequences of small population size: implications for plant conservation. Annual Review of Ecology and Systematics 24(1):217-242. https://doi.org/10.3732/ajb.1400024

Ensslin A, Sandner TM, Matthies SD (2011). Consequences of ex situ cultivation of plants: Genetic diversity, fitness and adaptation of the monocarpic Cynoglossum officinale L. in botanic gardens. Biological Conservation 144(1):272-278. https://doi.org/10.1016/j.biocon.2010.09.001

Ensslin A, Tschöpe O, Burkart M, Joshi J (2015). Fitness decline and adaptation to novel environments in ex situ plant collections: Current knowledge and future perspectives. Biological Conservation 192:394-401. https://doi.org/10.1016/j.biocon.2015.10.012

Ensslin A, Van de VyVer A, Vanderborght T, Godefroid S (2018). Ex situ cultivation entails high risk of seed dormancy loss on short-lived wild plant species. Journal of Applied Ecology 55(3):1145-1154. https://doi.org/10.1111/1365-2664.13057

Ensslinn A, Godefroid S (2019). How the cultivation of wild plants in botanic gardens can change their genetic and phenotypic status and what this means for their conservation value. Sibbaldia: The Journal of Botanic Garden Horticulture 17:51-69. https://doi.org/10.23823/Sibbaldia/2019.267

Ensslin A, Godefroid S (2020). Ex situ cultivation impacts on plant traits and drought stress response in a multi-species experiment. Biological Conservation 248:108630. https://doi.org/10.1016/j.biocon.2020.108630

Etisham-Ul-Haq M, Allnutt TR, Smith-Ramiarez C, Gardener MF, Armesto JJ, Newton AC (2001). Patterns of genetic variation in in and ex situ populations of the threatened Chilean vine Berberidopsis corallina, detected using RAPD Markers. Annals of Botany 87(6):813-821. https://doi.org/10.1006/anbo.2001.1420

Falk DA (1987). Integrated conservation strategies for endangered plants. Natural Areas Journal 7:118-123.

Frankham R, Bradshaw CJA, Brook BW (2014). Genetics in conservation management: Revised recommendations for the 50/500 rules, Red List criteria and population viability analyses. Biological Conservation 170:56-63. https://doi.org/10.1016/j.biocon.2013.12.036

Gargiulo R, Saubin M, Rizzuto G, West B, Fay MF, Kallow S, Trivedi C (2019). Genetic diversity in British populations of Taxus baccata L.: Is the seedbank collection representative of the genetic variation in the wild? Biological Conservation 233:289-297. https://doi.org/10.1016/j.biocon.2019.01.014.

Given DR (1987). What the conservationist requires of ex situ collections. In: Bramwell D, Hamann O, Heywood VH, Synge H (Eds). Botanic gardens and World Conservation Strategy. Academic Press, London pp 103-116.

Global strategy for plant conservation (GSPC) 2011-2020. Retrieved 2021 January 17 from https://www.cbd.int/gspc/targets.shtml

Gong X, Wu Q, Lu Y, Zhang Y (1998). Pollination biology of cultivated Magnolia delavayi. Acta Botanica Yunnanica 20(1):89-93

Guerrant EOJ, Fiedler PL (2004). Accounting for sample decline during ex situ storage and reintroduction. In: Guerrant EOJ, Havens K, Maunder M (Eds). Ex situ Plant Conservation: Supporting Species Survival in the Wild. Island Press, Washington pp 365-386.

Guimarães RA, Corrêa MKM, Chaves LJ, Naves RV, de Campos Telles MP, Soares TN (2019). Mating system and pollen dispersal in Dipteryx alata Vogel (Leguminosae): comparing in situ and ex situ conditions. Tree Genetics \& Genomes 15(28). https://doi.org/10.1007/s11295-019-1337-6

Hammer K (1984). Das domestikationssyndrom [The domestication syndrome]. Die Kulturpflanze 32(1):11-34. 
Hampe A, Petit RJ (2005). Conserving biodiversity under climate change: the rear edge matters. Ecology Letters 8(5):461467. https://doi.org/10.1111/j.1461-0248.2005.00739.x

Haskins KE, Pence V (2012). Transitioning plants to new environments: beneficial applications of soil microbes. In: Maschinski J, Haskins KE (Eds). Plant reintroductions in a changing climate: promises and perils. Society for Ecological Restoration, Center for Plant Restoration, Island Press, Washington pp 89-107.

Havens K, Guerrant EO, Maunder M, Vitt P (2004). Guidelines for ex situ conservation collection management: Minimizing risks. In: Guerrant EO, Havens K, Maunder M (Eds). EX situ Plant Conservation: Supporting Species Survival in the Wild. Island Press, Washington pp 454-473.

Havens K, Vitt P, Maunder M, Guerrant EO, Dixon K (2006). Ex situ plant conservation and beyond. BioScience 56:525532.

Hawkes JG, Maxted N, Ford-Lloyd BV (2012). The ex situ conservation of plant genetic resources. Springer Netherlands, Dordrecht pp 92-107.

Herbert R, Samuel S, Pattison G (1999). Using local stock for planting native trees and shrubs. In: Forestry Commission Practice Note 8. UK Forestry Commission, Edinburgh.

Hoban S, Schlarbaum S (2014). Optimal sampling of seeds from plant populations for ex-situ conservation of genetic biodiversity, considering realistic population structure. Biological Conservation 177:90-99. https://doi.org/10.1016/j.biocon.2014.06.014

Hoban S, Strand A (2015). Ex situ seed collections will benefit from considering spatial sampling design and species' reproductive biology. Biological Conservation 187:182-191. https://doi.org/10.1016/j.biocon.2015.04.023

Hoban S (2019). New guidance for ex situ gene conservation: Sampling realistic population systems and accounting for collection attrition. Biological Conservation 235:199-208. https://doi.org/10.1016/j.biocon.2019.04.013

Hoban S, Callicrate T, Clark J, Deans S, Dosmann M, Fant J, ... Griffith MP (2020). Taxonomic similarity does not predict necessary sample size for ex situ conservation: a comparison among five genera. Proceedings of the Royal Society B: Biological Sciences 287(1926):20200102 https://doi.org/10.1098/rspb.2020.0102

Husband BC, Campbell LG (2004). Population responses to novel environments: Implications for ex situ plant conservation. In: Guerrant EO, Havens K, Maunder M (Eds). Ex situ Plant Conservation: Supporting Species Survival in the Wild. Island Press, Washington pp 231-285.

Hyvärinen MT (2020). Rubus humulifolius rescued by narrowest possible margin, conserved ex situ, and reintroduced in the wild. Journal for Nature Conservation 55:125819. https://doi.org/10.1016/j.jnc.2020.125819

IUCN (2020). The IUCN red list of threatened species. Version 2020-1. Retrieved 2021 January 17 from https://www.iucnredlist.org

Kallow S, Trivedi C (2017). Collecting genetic variation on a small island. In: Sniezko RA, Man G, Hipkins V, Woeste K, Gwaze D, Kliejunas JT, McTeague BA (Eds). Proceedings of Workshop: Gene Conservation of Tree SpeciesBanking on the Future. May 16-19. Gen. Tech. Rep. PNW-GTR-963. US Department of Agriculture, Forest Service, Pacific Northwest Research Station, pp 129-136.

Kovács Zs, Barabás S, Csontos P, Höhn M, Honfi P (2019). Az óriás útifü (Plantago maxima Juss. ex Jacq.) ex situ védelembe vonása II. Élöhelypreferencia-vizsgálat [EX situ protection of the giant plantain (Plantago maxima Juss. ex Jacq.) II. Habitat preference studies]. Botanikai Közlemények 106(2):157-172. http://doi.org/10.17716/BotKozlem.2019.106.2.157

Lande R (1994). Risk of population extinction from fixation of new deleterious mutations. Evolution 48:14601469._https://doi.org/10.1111/j.1558-5646.1994.tb02188.x

Lauterbach D, Burkart M, Gemeinholzer B (2012). Rapid genetic differentiation between ex situ and their in situ source populations: an example of the endangered Silene otites (Caryophyllaceae). Botanical Journal of the Linnean Society 168(1):64-75. https://doi.org/10.1111/j.1095-8339.2011.01185.x

Lesica P, Allendorf FW (1995). When are peripheral populations valuable for conservation? Conservation Biology 9(4):753-760. https://doi.org/10.1046/j.1523-1739.1995.09040753.x

Li BJ, Wang JY, Liu ZJ, Zhuang XY, Huang JX (2018). Genetic diversity and ex situ conservation of Loropetalum subcordatum, an endangered species endemic to China. BMC Genetics 19:12. https://doi.org/10.1186/s12863018-0599-6

Li DZ, Pritchard HW (2009). The science and economics of ex situ plant conservation. Trends in Plant Science 14(11):614-621. https://doi.org/10.1016/j.tplants.2009.09.005

Li Q, Xu Z, He T (2002). Ex situ genetic conservation of endangered Vatica guangxiensis (Dipterocarpaceae) in China. Biological Conservation 106(2):151-156. https://doi.org/10.1016/S0006-3207(01)00240-3 
Liu U, Cossu TA, Davies RM, Forest F, Dickie JB, Breman E (2020). Conserving orthodox seeds of globally threatened plants ex situ in the Millennium Seed Bank, Royal Botanic Gardens, Kew, UK: the status of seed collections. Biodiversity and Conservation 29:2901-2949. https://doi.org/10.1007/s10531-020-02005-6

Lozada-Gobilard S, Pánková H, Zhu J, Stojanova B, Münzbergová Z (2020). Potential risk of interspecific hybridization in ex situ collections. Journal for Nature Conservation 58:125912. https://doi.org/10.1016/j.jnc.2020.125912

Marler TE, Lindstrom AJ (2020). Leaf nutrients of two Cycas L. species contrast among in situ and ex situ locations. Journal of Threatened Taxa 12(13):16831-16839. https://doi.org/10.11609/jott.6205.12.13.16831-16839

Marshall DR, Brown AHD (1975). Optimum sampling strategies in genetic conservation. In: Frankel OH, Hawkes JG (Eds). Crop Genetic Resources for Today and Tomorrow. Cambridge University Press, Cambridge pp 53-80.

Marshall DR (1989). Limitations to the use of germplasm collections. In: Brown AHD, Frankel OH, Marshall DR, Williams JT (Eds). The Use of Plant Genetic Resources. Cambridge University Press, Cambridge pp 105-120.

Maunder M, Higgens S, Culham A (2001). The effectiveness of botanic garden collections in supporting plant conservation: a European case study. Biodiversity and Conservation 10:383-401. https://doi.org/10.1023/A:1016666526878

Maunder M, Havens K, Guerrant EO, Falk DA (2004). Ex situ methods: A vital but underused set of conservation resources. In: Guerrant EO, Havens K, Maunder M (Eds). Ex situ Plant Conservation: Supporting Species Survival in the Wild. Island Press, Washington pp 3-20.

Miao YC, Su JR, Zhang ZJ, Lang XD, Liu WD, Li SF (2015). Microsatellite markers indicate genetic differences between cultivated and natural populations of endangered Taxus yunnanensis. Botanical Journal of the Linnean Society 177(3):450-461. https://doi.org/10.1111/boj.12249

Mounce R, Smith P, Brockington S (2017). Ex situ conservation of plant diversity in the world's botanic gardens. Nature Plants 3(10):795-802. http://doi:10.1038/s41477-017-0019-3

MSBP (2015). Seed Conservation Standards for 'MSB Partnership Collections'. Retrieved 2021 May 08 from http://brahmsonline.kew.org/Content/Projects/msbp/resources/Training/MSBP-Seed-ConservationStandards.pdf

Namoff S, Husby CE, Francisco-Ortega J, Noblick LR, Lewis CE, Griffith MP (2010). How well does a botanical garden collection of a rare palm capture the genetic variation in a wild population? Biological Conservation 143(5):1110-1117. https://doi.org/10.1016/j.biocon.2010.02.004

Németh A, Makra O (2011). A tartós szegfü (Dianthus diutinus) ex situ védelme - esettanulmány [Ex situ conservation of long-lasting pink (Dianthus diutinus) - case study] In: Verő Gy (Eds). Természetvédelem és kutatás a DunaTisza közi homokhátságon. Rosalia 6. kötet. Duna-Ipoly Nemzeti Park Igazgatóság, Budapest pp 353-380. https://fuveszkert.u-szeged.hu/images/kutatasok/dianthus_Rosaliacikk.pdf

Nonić M, Šijačić-Nikolić M (2019) Genetic diversity: sources, threats, and conservation. In: Leal Filho W, Azul A, Brandli L, Özuyar P, Wall T (Eds). Life on Land. Encyclopedia of the UN Sustainable Development Goals. Springer, Cham. https://doi.org/10.1007/978-3-319-71065-5_53-1

O'Donnell K, Sharrock S (2017). The contribution of botanic gardens to ex situ conservation through seed banking. Plant Diversity 39(6):373-378. https://doi.org/10.1016/j.pld.2017.11.005

Peregrym MM, Kónya EP, Bezsmertna O (2019). Artificial light at night as a new threat for the efficiency of ex situ plant conservation. Conference paper. Conference: 1st International Scientific Conference "Advances and Perspectives of Biodiversity Research and Conservation in Georgia” (May 20-22, 2019, Tbilisi, Georgia). https://doi.org/10.13140/RG.2.2.16500.19842

Petit RJ, El Mousadik A, Pons O (1998). Identifying populations for conservation on the basis of genetic markers. Conservation Biology 12 (4):844-855. https://doi.org/10.1111/j.1523-1739.1998.96489.x

Pineda B, Hidalgo R, Debouck D, Mejía M (2007). Multi-institutional distance learning course on the ex situconservation of plant genetic resources. Centro Internacional de Agricultura Tropical. CIAT. Cali, Colombia pp 205-216. ISBN $9789586940948 \quad$ Retrieved $2021 \quad$ January 09 from https://cgspace.cgiar.org/bitstream/handle/10568/54187/c_ex_situ.pdf?sequence=18is_Allowed=y

Pogorzelec M, Bronowicka-Mielniczuk U, Serafin A, Parzymies M (2020). The importance of habitat selection for the reintroduction of the endangered Salix lapponum L. in eastern Poland. Journal for Nature Conservation 54:125785. https://doi.org/10.1016/j.jnc.2020.125785

Prasse R, Kunzmann D, Schröder R (2010). Entwicklung und praktische umsetzung naturschutzfachlicher mindestanforderungen an einen herkunftsnachweis für gebietseigenes wildpflanzensaatgut krautiger pflanzen abschlussbericht. Deutsche bundesstiftung umwelt. [Development and practical implementation of nature 
conservation requirements for a certificate of origin for native wild plant seeds of herbaceous plants Final report. German Federal Foundation Environment] Retrieved 2021 January 09 from https://www.dbu.de/OPAC/ab/DBUAbschlussbericht-AZ-23931.pdf

Rauschkolb R, Szczeparska L, Kehl A, Bossdorf O, Scheepens JF (2019). Plant populations of three threatened species experience rapid evolution under ex situ cultivation. Biodiversity and Conservation 28:3951-3969. https://doi.org/10.1007/s10531-019-01859-9

Reyes-Valdés MH, Burgueño J, Singh S, Martínez O, Sansaloni CP (2018). An informational view of accession rarity and allele specificity in germplasm banks for management and conservation. PLoS One 13(2):e0193346 https://doi.org/10.1371/journal.pone.0193346

Rucińska A, Puchalski J (2011). Comparative molecular studies on the genetic diversity of an ex situ garden collection and its source population of the critically endangered polish endemic plant Cochlearia polonica E. Fröhlich. Biodiversity and Conservation 20(2):401-413. https://doi.org/10.1007/s10531-010-9965-Z

Schaal B, Leverich WJ (2004). Population genetic issues in ex situ plant conservation. In: Guerrant EO, Havens K, Maunder M(Eds). Ex situ Plant Conservation: Supporting Species Survival in The Wild. Island Press, Washington pp 267-285.

Schoen DJ, Brown AHD (2001). The conservation of wild plant species in seed banks: attention to both taxonomic coverage and population biology will improve the role of seed banks as conservation tools. BioScience 51(11):960-966. https://doi.org/10.1641/0006-3568(2001)051[0960:TCOWPS]2.0.CO;2

Schröder R, Prasse R (2013). Cultivation and hybridization alter the germination behavior of native plants used in revegetation and restoration. Restoration Ecology 21(6):793-800. https://doi.org/10.1111/rec.12018

Silva AR, Resende-Moreira LC, Carvalho CS, Lanes ECM, Ortiz-Vera MP, Viana PL, Jaffé R (2020). Range-wide neutral and adaptive genetic structure of an endemic herb from Amazonian Savannas. AoB Plants 12(1). https://doi.org/10.1093/aobpla/plaa003

Solberg SO, Yndgaard F, Palmè A (2015). Morphological and phenological consequences of ex situ conservation of natural populations of red clover (Trifolium pratense L.). Plant Genetic Resources 15(02):97-108. https://doi.org/10.1017/S1479262115000416

Tang R, Li Y, Xu Y, Schinnerl J, Sun W, Chen G (2019). In-situ and ex situ pollination biology of the four threatened plant species and the significance for conservation. Biodiversity and Conservation 29(2):381-391. https://doi.org/10.1007/s10531-019-01887-5

Thompson PA (1974). The use of seed-banks for conservation of populations of species and ecotypes. Biological Conservation 6(1):15-19. https://doi.org/10.1016/0006-3207(74)90036-6.

Tong YW, Durka W, Zhou WM, Zhou L, Yu DP, Dai LM (2020). Ex situ conservation of Pinus koraiensis can preserve genetic diversity but homogenizes population structure. Forest Ecology and Management 465:117820. https://doi.org/10.1016/j.foreco.2019.117820

Vitt P, Havens K (2004). Integrating quantitative genetics into ex situ conservation and restoration practices. In: Guerrant EO, Havens K, Maunder M (Eds.). Ex situ Plant Conservation: Supporting Species Survival in the Wild. Island Press, Washington pp 286-305.

Volis S (2017). Conservation utility of botanic garden living collections: setting a strategy and appropriate methodology. Plant Diversity 39(6):365-372. https://doi.org/10.1016/j.pld.2017.11.006

Volis S, Blecher M (2010). Quasi in situ: a bridge between ex situ and in situ conservation of plants. Biodiversity and Conservation 19(9):2441-2454. https://doi.org/10.1007/s10531-010-9849-2

Vrieling K, Saumitou-Laprade P, Cuguen PJ, van Dijk H, de Jong TJ, Klinkhamer PGL (1999). Direct and indirect estimates of the selfing rate in small and large individuals of the bumblebee pollinated Cynoglossum officinale L. (Boraginaceae). Ecology Letters 2:331-337. https://doi.org/10.1046/j.1461-0248.1999.00093.x

Wei X, Jiang M (2020). Meta-analysis of genetic representativeness of plant populations under ex situ conservation in contrast to wild source populations. Conservation Biology 35(1):12-23. https://doi.org/10.1111/cobi.13617

Wilson WD, Hutchinson JT, Ostrand KG (2017). Genetic diversity assessment of in situ and ex situ Texas wild rice (Zizania texana) populations, an endangered plant. Aquatic Botany 136:212-219. https://doi.org/10.1016/j.aquabot.2015.12.005

World Conservation Monitoring Centre (1998). Dipteryx alata. The IUCN Red List of Threatened Species. $\begin{array}{llllll}\text { e.T32984A9741012. } & \text { Retrieved } & 2021 & \text { January } & 17 & \text { from }\end{array}$ https://dx.doi.org/10.2305/IUCN.UK.1998.RLTS.T32984A9741012.en 
Xiao YE, Jin D, Jiang K, Hu YH, Tong X, Mazer SJ, Chen XY (2019). Pollinator limitation causes sexual reproductive failure in ex situ populations of self-compatible Iris ensata. Plant Ecology and Diversity 12(1):21-35. https://doi.org/10.1080/17550874.2019.1569170

Yao XH, Ye QG, Kang M, Huang HW (2005). Geographic distribution and current status of the endangered genera Sinojackia and Changiostyrax. Biodiversity Science 13:339-346. https://doi.org/10.1360/biodiv.050059

Zhang JJ, Ye QG, Yao XH, Huang HW (2010). Spontaneous interspecific hybridization and patterns of pollen dispersal in ex situ populations of a tree species (Sinojackia xylocarpa) that is extinct in the wild. Conservation Biology 24(1):246-55. https://doi.org/10.1111/j.1523-1739.2009.01357.x

Zhao Y, Noltie H, Mathew B (2000). Iridaceae. Flora of China 24:297-313.
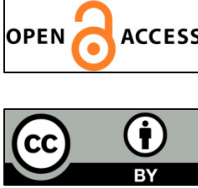

The journal offers free, immediate, and unrestricted access to peer-reviewed research and scholarly work. Users are allowed to read, download, copy, distribute, print, search, or link to the full texts of the articles, or use them for any other lawful purpose, without asking prior permission from the publisher or the author.

License - Articles published in Notulae Botanicae Horti Agrobotanici Cluj-Napoca are Open-Access, distributed under the terms and conditions of the Creative Commons Attribution (CC BY 4.0) License. (C) Articles by the authors; UASVM, Cluj-Napoca, Romania. The journal allows the author(s) to hold the copyright/to retain publishing rights without restriction. 